\title{
Analysis for Change in Health Sector Organization
}

\author{
I. H. Monrad Aas \\ Research Unit, Division of Mental Health and Addiction, Vestfold Hospital Trust, PO Box 2267, Tønsberg 3103, Norway
}

\begin{abstract}
Health sector organization is discussed in many countries of the world. Organization of sectors of the society is a complex issue. It may look difficult where to start and how to navigate through an analysis of health sector organization. The objective is to present an approach to analysis for change in health sector organization that can result in a broad information basis for choice of new organization. A process based framework to analysis for change in health sector organization was designed. The three major stages of the process are: solving problems by smaller change in organization, smaller or major change in organization and major change in organization. Major change in sector organization has the steps: change in sector organization type, number and bordering of geographic subunits, choice of accountability structure, network organization, internal health sector organization and plan for the change process. A new way for how to perform analysis for change in health sector organization is described. With the approach, improved overall information is likely to be achieved. It can be applied as a first step by countries considering new organization of the health sector. It should be followed up by selecting specific organizational alternatives for more detailed analysis. The described framework can help navigating through analysis for choice of future health sector organization.
\end{abstract}

Key words: Health sector, organization, reform.

\section{Introduction}

The market thinking and New Public Management (NPM) has not made choice of basic organizational structure for the health sector an outdated issue [1-4]. In fact, a tendency to recentralisation is seen in Europe, and sector analysis is a top research theme within developing countries $[5,6]$. In the new century, both traditional and newer forms of sector organization have been discussed in international literature and in numerous countries, for example in Latin America (like Brazil and Chile), Asia (like China, Indonesia, Nepal, Bangladesh), Africa (like South Africa, Egypt), Middle East (like Jordan), Australia, USA, countries of the former Eastern-Block and other European countries (like Slovenia, Spain, Italy, Nordic states and the UK) [7-30].

The question of organizational change for the health sector is a question for politicians, but what is decided based on political criteria, political compromise and who obtains strengthened power can have weaknesses

Corresponding author: I. H. Monrad Aas, Ph.D., research field: helth services research. E-mail: monrad.aas@siv.no.
[27]. In addition, international research has not identified a universally best way of organizing the health sector. One type of sector organization may fit the situation in one country, but does not comply well with the situation in another [31]. Frequently, organizational reform in different countries does not start with obtaining a broad overview of alternatives. Reform plans can be limited to considering one or a few alternatives without giving good reasons for why other alternatives can be excluded. However, broad understanding of alternatives means more knowledge to play with for the tailoring of new sector organization to a country's situation. The present study is a framework for obtaining a broad overview of information important for health sector organizational change. The framework should be applicable, in full or in part, in different countries, help in navigating through a more overall analysis by identifying necessary main points and a proposed sequencing of these points, and should result in a broader information basis for choice of new health sector organization.

Purpose with present study: to present an approach to analysis for change in health sector organization that 
Table 1 Stages of the framework for overall analysis for change in health sector organization.

\begin{tabular}{|l|l|}
\hline Major stages & Sub stages \\
\hline Smaller change in organization & $\begin{array}{l}\text { Mapping of problems } \\
\text { - Solutions without major change } \\
\text { - Mapping of what functions well }\end{array}$ \\
\hline Smaller or major changes in organization & Criteria for decision \\
\hline Major change in sector organization & $\begin{array}{l}\text { Change in sector organization type } \\
\text { - Number and bordering of geographic subunits } \\
\text { Accountability structures Network organization Internal health sector } \\
\text { organization } \\
\text { Change process plan }\end{array}$ \\
\hline
\end{tabular}

can result in a broad information basis for choice of new organization.

The present approach to analysis for change in health sector organization has three major stages and several sub stages (Table 1).

\section{Smaller Change in Organization}

Problems in the health service can release the idea of major change in sector organization, but major change in sector organization can take years to implement, have a significant cost tag, performance may deteriorate before improvement and it may take many years before a new sector organization works well [32-34]. Difficulties are easily underestimated [35]. Politicians may be tempted to overreact by proposing major change in sector organization. However, a problem related to health sector organization does not need to result in major change in sector organization.

\subsection{Mapping of Problems with the Present Organization}

Problems with the present organization should be mapped. Try to answer the question: what is the cause of the problems?

In the following, examples of health sector problems are given: (a) Problems with the present distribution of levels of care on different administrative/hierarchic levels. For example: Co-ordination problems between hospitals and primary care. Fragmentation of responsibility may be the result for episodes of care involving both levels; (b) Problems related to the decentralisation of administrative functions (planning, budgeting, goal formulation and achievement etc) on administrative levels. Examples: Contradicting goals for different organizational units and double work; (c) Problems which can be related to organization type, examples: $\left(c_{1}\right)$ Devolution of responsibility to local government has resulted in heterogeneity in policy, $\left(c_{2}\right)$ Difficulties with the co-ordination between health care and other sectors of society at local level. For psychiatric patients coordination between health care, social care and labour market authorities can be especially important; (d) Problems with the size and bordering of geographical subunits: $\left(\mathrm{d}_{1}\right)$ Efficiency problems for the total sector may result when responsibility is fragmented to many small organizational units, $\left(\mathrm{d}_{2}\right)$ When areas are large, information for a centralised management about local conditions can be limited. Such information can be important when for example a primary care organization wants to work according to the community diagnosis concept [36]; (e) Assessment of the need for changes in view of future challenges. The more rapid development of new innovations (for example new diagnostic procedures, treatments) needs organizations capable of following the development and evaluating the question of implementation.

\subsection{Solutions to Problems without Major Change in Health Sector Organization}

It is possible to consider other solutions than major change in sector organization first. Here are examples of solutions to the problems mentioned in section ' 1.1 '. Mapping of problems with the present organization: 
(a) For the co-ordination problems between hospitals and primary care, other solutions than major change in sector organization can be considered [37-39]. Examples: $\left(\mathrm{a}_{1}\right)$ ACT-teams (assertive community treatment) in psychiatry for treatment without admission to mental hospital and better follow up after discharge. Patients receive treatment by the ACT-teams visiting the home and become less vulnerable to coordination problems between hospitals and primary care, $\left(\mathrm{a}_{2}\right)$ development of individual care plans (especially for the chronically ill) with identification of who is responsible for what and when; (b) When decentralisation of administrative functions on administrative levels results in co-ordination problems, an example of work for improved co-ordination is: strengthened network collaboration, which includes coordinating goals and removal of double work; (c) For problems related to organization type, examples of solutions without changing organization type are: $\left(c_{1}\right)$ Heterogeneity of policy for local administrative levels with devolved authority can be attacked by having a clear national policy for the health sector and a legislation with national goals expressed in the new law, $\left(c_{2}\right)$ Co-ordination problems with other sectors (for example social service) at local level can be attacked by allocating the different sectors responsibility for the same areas, by having a common committee for groups of sectors with management and political level represented, common location of offices, sharing of information flows, co-ordinated planning and co-operation formulated as a goal; (d) Problems with the size and bordering of geographical subunits: $\left(d_{1}\right)$ When many small organizational units result in efficiency problems for the total health sector, merger is not the only solution. A part of the solution can be to increase supply of primary care close to overcapacity. Also, developed countries with a well organized primary care tend to have lower health care costs and improved health outcomes than those with a weaker [40-42], $\left(\mathrm{d}_{2}\right)$ If top management in large areas has problems with information about local conditions, an alternative solution (to splitting such areas into smaller) can be improvement of information systems and decentralisation of functions to lower management levels; (e) If responsibility for the health service is split on many small organizations, the organizations can be too small to have sufficient competence for evaluation of new innovations. Merger into larger organizations is not the only alternative. Organizational networks can improve communication between organizations resulting in more rapid diffusion of innovations. Also, national level organizations, especially established for the purpose, can evaluate new innovations and give advice to the health service.

\subsection{Mapping of What Functions well in the Present Organization}

What functions well in the present organization? It may be wise to perform a mapping of this as well as of problems. Change in health sector organization does not need to be total, but can be partial. What functions well does not need change.

\section{Smaller or Major Changes in Organization}

\subsection{Criteria for Proceeding to Major Organizational Change}

The decision to proceed from ' 1.2 Solutions to problems without major change in health sector organization' to 'Major change of sector organization type' can occur on the basis of several criteria: (a) Existing problems should be sufficiently large to defend the costs with organizational change; (b) The problems should not only be found in one part (or a few parts) of the organization, but be general; (c) Other solutions than major change in sector organization have been tested out and found not to be effective; (d) Problems in the health service can be considered related to existing sector organization; (e) On the basis of political criteria, for example: ideological shift in a country may lead to change in hospital sector organization from devolution to private organization. 


\section{Major Change in Sector Organization}

In international literature, the terms decentralisation and public administration are related to major change in sector organization. The term decentralisation is frequently used concerning the territorial distribution of power to organizational subunits, for example the spread of the health sector to cover the population's needs in a country's land area [31, 43-45]. The public administration approach is about distribution of authority and responsibility within a national political and administrative structure [46]. There is no international agreement concerning terminology for the different forms of sector organization and internationally we find several typologies of health care systems [3]. In the present study, six organizational categories are included in the analysis: deconcentration, devolution, 'independent' organization and private organization, hybrid forms of organization, accountability structures and network organization. A detailed presentation of organizational alternatives is not given. Readers needing more encompassing presentation of organizational categories (with their pros and cons) should look elsewhere, for example [31, 43-45, 47].

It is necessary to decide goals for the new organization. Arguments for and against each alternative for own health service should be collected and conclusion searched for by synthesis. Also, a thorough analysis may lead to consensus on one best solution [45].

\subsection{Change in Sector Organization Type}

Countries reconsidering health sector organization can be in different situations: (a) the country's general administrative organization cannot easily be changed. Responsibility for health care should be allocated to the existing administrative levels; (b) existing subdivision of a country in geographic areas is difficult to change. A new organization must use these areas; (c) choice of health sector organization type can be done independently of existing general administrative organization and/or geographic units.

Several factors are important for the choice of organizational form, like: previous experiences with different organization types; the importance of organizational adaptation to local conditions; responsibility for economic matters should rest with the organization only or responsible political bodies should control budgets; the importance of national level control; the importance of vertical (between levels of care) and horizontal (for example between different hospitals) co-ordination.

Deconcentration is an organizational form used when national level political control is considered important. We find a chain of command from the Ministry of Health to lower hierarchic levels. Management can occur by instructions down the chain of command. If a high degree of standardization within a sector is important, such centralised decision-making can be right, but it should be noticed that the implementation of top-down policies can become poor and the organization can be little responsive to consumer needs [48]. From the administrative history of the UK, deconcentration is well known. Before market reform, the NHS (the National Health Service) was organized by deconcentration [49]. A health service organized by deconcentration and with a high degree of decentralisation of responsibility is an alternative to devolution and 'independent' organization, but there is no local democracy to detect problems and defend the interests of the population. Degree of decentralisation can vary with the number and significance of tasks performed at lower levels and the degree of control wanted by the central level. Deconcentration offers a good possibility for control of total costs.

Devolution is the organizational type chosen when local political control is wanted. With local democracy, the legitimacy of the organization can become greater locally. Involvement of local communities can have benefits [35]. Different preferences and needs of local populations become more visible for those who decide, but health care users' perspectives may be different from those of policy makers [35]. Improved 
tailoring of public activity to local needs can be a goal. For primary care, geographic heterogeneity in need may release a wish to decentralise. More decision-making by many units managed by local democracy may result in more experimentation. New technology and the growth in knowledge can question the relevance of management by smaller local democracies to the advantage of larger organizations with greater accumulation of competence [50].

Independent' organization and private organizations are chosen when the interest for political control is limited. Management gets a higher freedom to act and can act swiftly on the basis of economic criteria rather than political considerations. 'Independent' organizations can serve public goals. If national goals are formulated, a tension exists between obtainment of national goals and local management. Change from politically managed organizations to 'independent' organization requires the political community to redefine its role. Political influence can focus more on general policy questions and strategic issues. Legislation can set limits for the political influence. The information flow, both formal and informal, between public authorities and the health sector can be important for the nature and degree of political influence. Ideology can play a role for the choice between public and private organization.

The 'independent' and private organizational forms can be publicly owned and have some public control (enterprises/autonomous trusts/companies with public control of the shares or publicly controlled foundations). When 'independent' organization is used: (a) each region can be 'independent' organizations; (b) a level of care (for example hospitals) is organized by 'independent' organization; and (c) single organizations (for example primary care centres or hospitals) are 'independent' organizations. Having a highly fragmented health service with much profit thinking can mean some problems, like: difficult to obtain rapid and good national control in case of pandemics and reduced interest in health promotion and prevention [21]. It may make sense to learn from more traditional public sector organization. For outsourcing, savings in costs can be obtainable, but also other changes may occur, like reduction in union power, problems with service quality and reduction in employee morale [28, 30, 51].

Hybrid organization. Change encompassing all health care in a country can look too much and decision is taken to change organization for only one level of care. Responsibility for primary care is more easily allocated to smaller geographic entities (for example municipalities with devolved authority). For hospitals, a different organization can look relevant. Hospitals need larger catchment areas or they compete for the patients. Hospitals can be: (a) 'independent' organizations owned by the state or by a lower administrative level or private organizations serving public goals; (b) Responsibility for hospitals can be given to larger regions with devolved authority; (c) Smaller geographic units form organizations of co-operation (which run hospitals) or some smaller geographic units (for example municipalities) own hospital enterprises and others buy hospital services from them; (d) The total hospital sector is organized by deconcentration.

\subsection{Number and Bordering of Geographic Subunits}

The next step can be considering the question of geographic subunits. To decide the division of a country into geographic subunits we need to find: the number of geographic areas and bordering of areas. Mathematical analysis has been developed for determination of the number of facilities, optimal location of facilities and the number of specialities a service organization should have [43]. When it comes to questioning existing location of facilities (for example hospitals), major change cannot be considered realistic.

The number of geographic areas. Several factors can contribute to determination of the number of geographic areas, like: economies of scale, span of 
control for the central level, increased coordination difficulties for large organizations [45], services involving high and to some degree instable costs can make it necessary to distribute the expenditures on a larger population, large areas can result in enhancement of competence and less parallel work and reduce the need for detailed control through legislation and other mechanisms, for patients distance to home can be shorter with many small organizational units, for physicians greater job satisfaction has been found in smaller organizations [52], many small organizations give a thin spread of competence (for example managerial), but can reduce distance between the population and those who decide.

On the basis of economic information the number of geographic subunits can be calculated. Example: The costs per visit for primary care practices can be determined empirically [53]. If we find lowest costs per visit for a practice with 11,000 visits per year [54] and we know the number of visits per year for the population in an area (for example 33,000), the most advantageous number (n) of clinics in the area would be: $n=33,000 / 11,000=3$. But such an area could also need a central management unit. We find a central management unit to have its lowest costs per clinic when the number of clinics is six. From an economic point of view an area, with 33,000 visits per year, is too small. Subdivision of the country into areas, which release 66,000 visits per year, should be chosen. Total number of such geographic subunits for a country is found by dividing the estimated total number of visits per year by 66,000 .

The many services a hospital produce have different scales for the production, but it is not just to calculate optimum scale for the production of each service and decide hospital size based on a compromise between the different optimum scales. A relationship between volume and quality exists. Large hospitals with high volumes result in better outcomes [55-57]. Small organizational units, however, can solve tasks in co-operation by network organization. The networks can be designed with a sharing of tasks allowing greater volumes. In a country with public health care, several hospitals can belong to the same area. Analysis can be done for necessary central management unit size for different combinations of hospitals and economies of scale decide which combination of hospitals is right. When sub-national levels are to deliver most health care, their size should be large enough to have an efficient mix of health services. An optimal size has been proposed to be a geographically compact area with between 50,000 and 500,000 inhabitants [58].

The bordering of areas. For many countries, the pre-existing subdivision into areas can be used as a starting point. Improvements are done by adjustment of borders and merger of geographic units. For a more encompassing analysis, several principles can be used to determine bordering of geographic areas: (a) Division of a country into functional geographic units. Basis for division into functional areas can be a combination of population number, travel distances, the existence of a centre with a varied supply of services and interdependency of centre and surrounding area. If large enough, such a functional area could offer a more comprehensive supply of health care; (b) Subdivision of a country into areas similar in population demand/need for health care. Economies of scale for the service-producing units decide the magnitude of demand each should take care of [59]; (c) Subdivision on the basis of geographic criteria. Equity of access irrespective of place of living is wanted. Area borders are chosen to minimise the patients travelling time. Utilization may drop as travelling time/costs increases; (d) in some countries, a subdivision into areas on the basis of historical/cultural/linguistic/ethnic criteria may be the natural choice.

\subsection{Accountability Structures}

After scrutiny of the relevance of the different organizational types, choice of accountability structures should be considered. First of all, a health service is morally accountable to its patients. Feedback 
from the patients can come from patient satisfaction questionnaires, patient complaints and malpractice litigation [60]. The role of accountability structures should not be overlooked. Studies have shown that being held responsible can affect human behaviour [61]. Chosen organization type has consequences for choice of accountability structure. We can speak about four types of accountability structures:

(a) Political level/democratic assemblies can be accountability structures. A country's government/national assembly can be accountability structures for deconcentrated organizations and local political level for devolved organizations. 'Independent' organizations and private organizations are supposed to be more independent of political control, i.e. local and national political levels are less relevant accountability structures.

(b) National level representatives can be accountability structures [45, 62]. An example is governors (and chief medical officers) in each region who supervise that laws are followed, quality lives up to standards and budgets comply with national economic plans. Governors and chief medical officers can supervise both devolved and deconcentrated organizations. 'Independent' organizations under public control can be similarly supervised. For private health care, governors and chief medical officers can supervise that laws are followed and quality lives up to standards.

(c) Governance by for example boards is a well-known accountability structure for 'independent' and private organizations, public-private partnerships and outsourcing. It should be clear to whom these types of organizations are accountable, with which obligations and rights. Also, for more traditional sector organizations governance by boards can have a role to play. Governance mechanisms can include regulatory and negotiating arrangements [45, 50, 63-65].

(d) Purchasing agencies can function as accountability structures [66]. This is especially relevant in organizational models with public competition. The purchasing agencies can measure provider performance, require providers to follow quality standards and perform active quality assurance.

\subsection{Network Organization}

The next step can be to consider network organization. Performance of health systems is related not just to the organization of each unit, but also to how units relate to each other [32, 67-69]. With high social capital, know-how can more easily flow from one organization to another. The pooled resources of a network can become greater than the sum of resources was before networking started. Not at least mental health is requiring when it comes to cooperation between different parts of health care and other sectors [70]. Organizations considering network organization can have many different motives, like: own organization is too small to keep updated with the increase in knowledge; joint projects for new developments; more standardized patient treatment; improvement in communication and coordination necessary for more seamless care; economies of scale (for example sharing of some administrative functions); reduced duplication of services and general enhancement of human capital. In the market oriented US health service, network organization involves a number of organizations [71-74].

For organizations considering joining a network, four questions are central: What should the collaboration be about? What can the organization achieve by joining the network? By joining the network all wishes cannot be fulfilled, but which compromises with the other organizations are acceptable? Are other solutions, than joining a network, better to achieve goals?

(a) Type of organizations. Adding the right kind of organizations to a network is important [75]. A network success can be dependent on selection of right partners. For other hospitals, university hospitals can be popular partners, but they are not the only alternative. Smaller hospitals can be organized in networks. They can develop common competence and 
share competence. Several factors are important for how well organizations are suited to each other for collaboration, like similarity in values and culture, alignment of objectives, complementarity of resources, relative size and strength [76, 77].

(b) Network size is a factor. Networks should not just be made as large as possible. Large networks can be more complicated to manage, i.e. have more conflicting interests among members and more complicated communication. When networks increase considerably in size, it is likely that organizations with little need will be included. A lower number of connected organizations may be more efficient [75]. It is well possible that different networks have different optimum sizes and that inclusion of more participants gradually decreases benefit.

\subsection{Internal Health Sector Organization}

The next problem to address is choice of internal organization $[50,78]$. For internal sector organization, centralisation and decentralisation are important terms. Centralisation can give better possibilities for setting standards and avoidance of duplication of services [25, 45]. For decentralisation, a number of advantages have been proposed, like: greater awareness of community needs, information important for decisions is more easily obtained, direct nature of channels between servers and clients, improved organizational responsiveness with more effective adjustment to the preferences of the local population, improved job satisfaction and use of knowledge and experience found in local staff, entrepreneurship is stimulated and strengthened feeling of responsibility [25, 43, 45]. However, when responsibilities are distributed on different levels of local government and many units of the same level, coordination problems must be counted upon. Not at least for episodes of care involving more than one level.

4.5.1 Determination of the number of hierarchic levels in deconcentrated organizations

The problem of finding the number of hierarchic levels, which gives the lowest costs, can be analysed by a mathematical method [43], but good cost information makes it possible to calculate costs for designs with a different number of levels by simply adding cost elements. The different functions in health care can have different degrees of decentralisation. Search for optimal mix of central and decentralised control becomes important. Analysis can show a clear need for having different levels to distribute functions on. For example, a high degree of centralisation for purchase of expensive equipment and contracting with external providers of services (for example laundry) and elective advanced surgery versus high degree of decentralisation for primary care and some psychiatry. De- institutionalizing care for mentally ill is well known, but before de-institutionalizing the capacity of primary care to diagnose and treat should be evaluated [79]. In general, optimal balance in capacity between hospitals and primary care should be searched for [80].

4.5.2 Determination of the number of administrative levels with devolved authority

The question of how many levels of local government which are needed to take care of the health sector can be analyzed:

(a) For each level of care economy of scale is analyzed. If the most advantageous organization size can be found on the basis of economic criteria, there should be a demand corresponding to this size. Good epidemiologic information can identify areas with a population size (and needs) resulting in a demand of approximately the right size [59]. Primary care and hospitals can have clearly different population sizes as the most advantageous. The result easily becomes that different levels of local government are needed and made responsible for different levels of care;

(b) The possibility for incomes for lower levels of government. Sub-national levels can have right both to levy taxes and/or receive grants from the central government. The power of sub-national levels can be considered related to the right to levy taxes and the right to take decisions concerning spending [58]. If 
expenditures are high (and even unstable) and the transfer of economic resources from central authorities is small, larger geographic units are needed. Division of a country into larger geographic units can mean fewer levels with devolved authority;

(c) A compromise between the conclusions for point's a-b should be reached. It has been proposed that more than four levels can result in a too bureaucratic organization [34].

4.5.3 Distribution of power over the decisions made by 'independent' organizations with area responsibility, like regional hospital enterprises

We can speak about three types of such decentralisation changes: decentralisation without change in internal organizational structure, change in internal organizational structure and delegation [50, 78].

(a) Decentralisation without change in internal organizational structure. It is not only decisions on daily production matters which can be decentralised, but also responsibilities like budgeting, goal achievement, economic result and implementation of quality assurance programs. For the functioning of a decentralised organization, information and co-operation between hierarchic levels is necessary. Change in supervision from and feedback to the CEO can be an important part of the change. A reporting system can be basis for communication between departments and CEO;

(b) Change in internal organizational structure. Change in the number of hierarchic levels and divisionalization are such decentralisation changes [78]. In the design of an organization, the number of levels is of course a central question. An organization with a low number of levels is more decentralised than a taller, ceteris paribus. With decrease in number of levels, fewer leaders are needed and the chain of command becomes shorter, but control span increases. Large organizations can have problems of control [81]. To divisionalize has been viewed as a solution to the problem. Divisionalizing can mean the splitting of an organization into units (divisions) where each division is responsible for an area. The division form is found in many larger corporations and is a form of decentralization [82]. The divisions can be large and are to a great extent self governed with responsibility for economic result;

(c) Delegation. Delegation means transfer of tasks from superiors to subordinates. The superior decides the transfer. Subordinate responsibility is increased, but final responsibility rests with the manager. Before delegation, evaluation of the subordinates trustworthiness and competence should be done. Delegation can be considered for functions limited in time $[45,50,78,83-85]$.

\subsection{Plan for the Change Process}

For a country, the different organizational alternatives can mean highly different change processes. Before deciding that one alternative is best, it can be wise to obtain a general overview of implications of the change process for different alternatives. Problems with the change should not be underestimated. Change processes can be a balancing act requiring tact towards differing interests. Change in health sector organization needs to be guided by an overall plan for the change process and this is the last step of the analysis.

$\left(a_{1}\right)$ Before reform it should be kept in mind that organizational change, of the magnitude considered here, costs. Mapping should be done of necessary changes in housing, equipment, number and categories of personnel, which will be needed in the different parts of the new organization (including management). $\left(a_{2}\right)$ Having a new organization can also mean that personnel need learning new ways of doing things, new routines should be developed, information systems redesigned [86] and personnel's values changed [87]. $\left(a_{3}\right)$ How to provide all old (as long as they exist) and new organizational units with financial resources during reform should be planned. $\left(a_{4}\right)$ Future changes in need (due to for example an increased number of 
elderly) should also be taken into consideration. (b) The relationship to other sectors of society for the new organization should be clarified. For example: are new ways of co-ordination between health and social care necessary for patients with mental health problems? (c) The contents of the organizational change process itself should be planned. This includes factors like: identification and sequencing of the elements of the change process, in which way should different parts of the organization be involved, authority and responsibility for each level is made clear for the entire change process, training of managers is important as substantial change in complex systems requires sustained leadership at all levels [88], planning for information of personnel, formation of groups to work with the change, support for the change is important and identification and engagement of champions for the change is a part of the change strategy. (d) Timing of the organizational change process is important: $\left(d_{1}\right)$ when should the process be started? $\left(\mathrm{d}_{2}\right)$ Implementation can be done gradually geographically and/or by a gradual transfer of functions to the new organization over a period of several years. The time for implementation of different parts of the reform in different parts of the organization is decided in a timetable. $\left(d_{3}\right)$ When should the change process be finished? (e) Advantages and disadvantages with the present and new organization should be summed up. Is it possible to find a reasonable expression of benefits and costs and will net benefits (benefit minus costs) increase by the reorganization? (f) Before reform is decided, experiences with previous reforms can be taken into consideration. (g) The goals with the reorganization should be formulated. The degree to which these goals have been reached should be investigated after the finish of the organizational change process. (h) When the overall plan for change has been worked out according to the steps a-g, decision must be taken. If necessary, organizational designs can be made for more than one organizational alternative and comparative analysis performed. A basic question is which way of organization gives the best fulfilment of expressed objectives.

\section{Discussion}

Change in health sector organization is a complex problem. Before final decision, a thorough analysis should be performed. Following the described process can lead to a more thorough overall analysis. When a country focuses just on a specific alternative (or a few), lack of knowledge about how to perform broad analysis can be the cause. The present analysis can be followed up with a more detailed analysis of specific alternatives. Also, learning can occur from how other countries solve problems, from their mistakes and which solutions functions well. In the present approach, focus is mainly on sector organization of providers, less on purchasers and bodies financing health care (for example sickness funds). The presented thinking is applicable to countries with different organizational starting points, i.e. private, more fragmented and complex health services, hybrid, and more traditional public health sectors. Not all points of the approach are equally relevant in all countries, but a country focusing for example only on public-private partnership in its reform thinking should be able to answer the question why most of the points mentioned here (or the thinking they represent) lack relevance.

Health systems vary widely in performance and performance has been proposed to be related to organization $[69,89]$, but it should be kept in mind that no organization is perfect. If claims are made that major organizational change will make a difference to daily clinical decisions, this is not credible without giving good reasons for the claim. When sector organization is changed, the change can mean going from one type of problems to other. In a country, legitimacy and cultural fit is important for sector organization [31].

The tendency to recentralisation and the fact that both more traditional and newer forms of sector organization are in use in the world make it relevant to 
have both traditional and newer forms of sector organization represented in the present study. They represent different ways of thinking. The total health service can have a mix of organizational forms. Not only for different levels of care, but also for the same level of care. Primary care should not be forgotten. Strong primary care is known to be associated with improved health outcomes and lower costs [41, 42].

During the organizational change process flexibility may be necessary as: the planned content of the reform needs adjustment, the time-table must be sacrificed as things take longer time than planned, and change in situational factors (for example the economic situation of the country is changed and increased expenditures become impossible). Before the reform process is started, it can be necessary to develop a strategy for short-term problem solving. It can be politically impossible to await the effects of a larger reorganization. Also, solutions to problems without basic change in health sector organization have a role to play as temporary changes.

\section{Alternatives to Change in Organization}

Focus on organizational change only is a limitation with the present study. The tools of health policy, like financing methods, legislation, planning systems, and negotiating procedures $[37,50,90,91]$ should not be forgotten. Change in tools of health policy, without changing sector organization, is an alternative. Different combinations of organizational types and tools of health policy (for example different financing methods) are possible and choice of combination dependent on goals.

\section{Conclusions}

Before change in sector organization, solutions to problems without major change in health sector organization should be searched for. The presented total approach for analysis of health sector organization is intended to be a framework for broad analysis, has main points in a logical sequence, sub-points important for change and numerous factors important for choice between the different organizational alternatives. The resulting broader understanding means more knowledge to play with. The proposed process should be followed up with a more detailed analysis of specific organizational alternatives. Change in health sector organization needs to be guided by an overall plan for the change process. The presented thinking is applicable to countries with different organizational starting points and problems.

\section{References}

[1] Atun, R. 2007. Privatization as decentralization strategy. In: Saltman RB, Bankaukaite V, Vrangbæk K, editors. Decentralization in health care. Maidenhead: McGraw-Hill Open University Press.

[2] Buchan, J. 2000. "Health Sector Reform and Human Resources: Lessons from the United Kingdom." Health Policy and Planning 15: 319-25.

[3] Lee, S-Y, Chun, C-B, Lee, Y-G, and Seo, N. K. 2008. "The National Health Insurance System as One Type of New Typology: the Case of South Korea and Taiwan." Health Policy 85: 105-13.

[4] Warwick, P. 2007. "Back to the Future in NHS Reform." Journal of Health Organization and Management 21: 194-204.

[5] Gonzalez-Block, M. A. 2004. "Health Policy and Systems Research Agendas in Developing Countries." Health Research Policy and Systems 2: 6 (doi: 10.1186/1478-4505-2-6).

[6] Saltman, R. B., Bankauskaite, V., and Vrangbæk, K. 2007. Introduction: the question of decentralization. In: Saltman RB, Bankaukaite V, Vrangbæk K, editors. Decentralization in health care. Maidenhead: McGraw-Hill Open University Press.

[7] Albreht, T., and Klazinga, N. 2009. "Privatisation of Health Care in Slovenia in the Period 1992-2008." Health Policy 90: 262-9.

[8] Atkinson, S., and Haran, D. 2004. "Back to Basics: does Decentralization Improve Health System Performance? Evidence from Cearta in North-east Brazil." Bulletin of the World Health Organization 82: 822-7.

[9] Atkinson, S., Cohn, A., Ducci, M., Fernandes, L., and Smyth, F. 2008. "Promotion and Prevention within a Decentralized Framework: Changing Health Care in Brazil and Chile." International Journal of Health Planning and Management 23: 153-71.

[10] Borissov, V., and Rathwell, T. 1996. "Health Care Reforms in Bulgaria: An Initial Appraisal." Social Science 
\& Medicine 42: 1501-10.

[11] Bossert, T. J., Laranaga, O., Giedion, U., Arbelaez, J. J., and Bowser, D. M. 2003. "Decentralization and Equity of Resource Allocation: Evidence from Colombia and Chile." Bulletin of the World Health Organization 81: 95-100.

[12] Byrkjeflot, H., and Neby, S. 2008. "The end of the Decentralized Model of Healthcare Governance?" Journal of Health Organization and Management 22: 331-49.

[13] Cockcroft, A., Andersson, N., Milne, D., Hossain, M. Z., and Karim, E. 2007. "What did the Public Think of Health Services Reform in Bangladesh? Three National Community-based Surveys 1999-2003." Health Research Policy and Systems 5: 1 (doi: 10.1186/1478-4505-5-1).

[14] Collins, C., Araujo, J., and Barbosa, J. 2000. "Decentralising the Health Sector: Issues in Brazil." Health Policy 52: 113-27.

[15] Collins, C., Omar, M., Adhikari, D., Dhakal, R., Emmel, N., Dhakal, M. R., Chand, P., Thapa, D., and Singh, A. 2007. "Health System Decentralization in Nepal: Indentifying the Issues." Journal of Health Organization and Management 21: 535-45.

[16] Exworthy, M., and Frosisni, F. 2008. "Room for Manoeuvre? Explaining Local Autonomy in the English National Health Service.” Health Policy 86 (2-3): 204-12.

[17] Goddard, M., and Mannion, R. 2006. "Decentralising the NHS: Rhetoric, Reality and Paradox." Journal of Health Organization and Management 20: 67-73.

[18] Hagen, T. P., and Kaarbøe, O. M. 2006. "The Norwegian Hospital Reform of 2002: Central Government Takes over Ownership of Public Hospitals." Health Policy 76: 320-33.

[19] Heywood, P., and Harahap, N. 2009. "Public Funding of Health at the District Level in Indonesia after Decentralization-Sources, Flows, and Contradictions." Health Research Policy and Systems 7: 5 (doi: 10.1186/1478-4505-7-5).

[20] Janecka, I. P. 2009. "Is US Health Care an Appropriate System? A Strategic Perspective from Systems Science." Health Research Policy and Systems 7: 1 (doi: 10.11186/1478-4505-7-1).

[21] Liu, Y. 2004. "China's Public Health-care System: Facing the Challenges." Bulletin of The World Health Organization 82: 532-8.

[22] Lopez-Casanovas, G. 2002. "Devolution of Health Care in Spain to the Regions becomes Reality." Eurohealth 8: 36-8.

[23] Martin-Moreno, J. M., Claveria, A., Gorgojo, L., and Peiró, S. 2009. "Spain: a Decentralized Health System in Constant Flux." BMJ 338: b1170.

[24] Mosca, I. 2005. Health care expenditure and decentralization: a national and international empirical analysis for OECD countries. Lugano: Faculty of Economics, University of Lugano (A Thesis).

[25] Mosca, I. 2006. "Is Decentralization the Real Solution? A Three Country Study." Health Policy 77: 113-20.

[26] Peckham, S., Exworthy, M., Powell, M., Greener, I. 2008. "Decentralizing Health Services in the UK: a New Conceptual Framework." Public Administration 86: 559-80.

[27] Saltman, R. B., and Vrangbæk, K. 2007. Drawing lessons for policy-making. In: Saltman RB, Bankaukaite V, Vrangbæk K, editors. Decentralization in health care. Maidenhead: McGraw-Hill Open University Press.

[28] Siddiqi, S., Masud, T. I., and Sabri, B. 2006. "Contracting but not without Caution: Experience with Outsourcing of Health Services in Countries of the Eastern Mediterranean Region." Bulletin of the World Health Organization 84: 867-75.

[29] Tediosi, F., Gabriele, S., and Longo, F. 2009. “Governing Decentralization in Health Care under Tough Budget Constraint: what can we learn from the Italian experience?" Health Policy 90: 303-12.

[30] Young, S. 2008. "Outsourcing in Public Health: a Case Study of Contract Failure and its Aftermath." Journal of Health Organisation and Management 22: 446-64.

[31] Vrangbæk, K. 2007. Towards a Typology for Decentralization in Health Care. In: Saltman RB, Bankaukaite V, Vrangbæk K, editors. Decentralization in health care. Maidenhead: McGraw-Hill Open University Press.

[32] Ham, C. 2009. "Lessons from the Past Decade for Future Health Reforms." BMJ 339: 1118-20.

[33] Jenkins, R., McCulloch, A., Friedli, L., and Parker, C. 2002. "Developing a National Mental Health Policy." East Sussex : Psychology Press Ltd.

[34] Mills, A., Vaughan, J. P., Smith, D. L., and Tabibzadeh, I. 1990. Health System Decentralization. Concepts, issues and country experience. Geneva: World Health Organization.

[35] Jenkins, R., McDaid, D., Brugha, T., Cutler, P., and Hayward, R. 2007. The evidence base in mental health policy and practice. In: Knapp M, McDaid D, Mossialos E, Thornicroft G, editors. Mental health policy and practice across Europe. Maidenhead: McGraw-Hill Open University Press.

[36] Haglund, B. J. A. 1988. "The Community Diagnosis Concept-a Theoretical Framework for Prevention in the Health Sector." Scandinavian Journal of Primary Health Care 6 (1): 11-21.

[37] Aas, I. H. M. 1999. Styring av helsetjenesten. Mangfold og muligheter [Managing the health service. Many alternatives and posibilities]. Oslo: Kommuneforlaget.

[38] Tjerbo, T., and Kjekshus, L. E. 2005. "Coordinating Care: 
Lessons from Norway." International Journal of Integrated Care 5 (2): 1-9.

[39] Wadman, S., Strandberg-Larsen, M., and Vrangbæk, K. 2009. "Coordination between Primary and Secondary Healthcare in Denmark and Sweden." International Journal of Integrated Care 9 (12): 1-14.

[40] Coulter, A. 1996. "Why should Health Services be Primary Care-led?" Journal of Health Services Research and Policy 1: 122-4.

[41] Mulley, A. G. 2009. "The Need to Confront Variation in Practice." BMJ 339: 1007-9.

[42] Starfield, B., Shi, L., and Macinko, J. 2005. "Contribution of Primary Care to Health Systems and Health." The Milbank Quarterly 83: 457-502.

[43] Kochen, M., and Deutsch, K. W. 1980. Decentralization. Sketches toward a rational theory. Cambridge Massachusetts: Oelgeschlager, Gunn \& Hain, Publishers Inc.

[44] Smith, B. C. 1985. Decentralization. The territorial dimension of the state. London: George Allen \& Unwin.

[45] Vrangbæk, K. 2007. Key factors in assessing decentralization and re-centralization in health systems. In: Saltman RB, Bankaukaite V, Vrangbæk K, editors. Decentralization in health care. Maidenhead: McGraw-Hill Open University Press.

[46] Bossert, T. 1998. "Analyzing the Decentralization of Health Systems in Developing Countries: Decision Space, Innovation and Performance." Social Science \& Medicine 47: 1513-27.

[47] Saltman, R. B., Bankauskaite, V., and Vrangbæk, K. 2007. Decentralization in health care. Maidenhead: McGraw-Hill Open University Press.

[48] Salter, B. 1994. "Change in the British National Health Service: Policy Paradox and the Rationing Issue." International Journal of Health Services 24: 45-72.

[49] Ham, C. 1991. The New National Health Service. Oxford: Radcliffe Medical Press Ltd.

[50] Bankauskaite, V., and Saltman, R. B. 2007. Central issues in the decentralization debate. In: Saltman RB, Bankaukaite V, Vrangbæk K, editors. Decentralization in health care. Maidenhead: McGraw-Hill Open University Press.

[51] Macinati, M. S. 2008. "Outsorcing in the Italian National Health Service: Findings from a National Survey." International Journal of Health Planning and Management 23: 21-36.

[52] Schulz, R., and Schulz, C. 1988. "Management Practices, Physician Autonomy, and Satisfaction. Evidence from Mental Health Institutions in the Federal Republic of Germany." Medical Care 26: 750-63.

[53] Aas, I. H. M. 1991. Poliklinikker og dagkirurgi. Virksomhetsbeskrivelse for ambulant helsetjeneste
[Outpatient clinics and daysurgery. Desribing the activity of ambulatory care]. Göteborg: Nordiska Hälsovårdshögskolan, NHV-rapport 1991:4.

[54] Berkelhammer, J. E., and Rojek, K. J. 1988. “An Analysis of Revenues and Expenses in a Hospital-based Ambulatory Pediatric Practice." American Journal of the Diseases of the Child 142 (5): 551-4.

[55] Birkmeyer, J. D., Siewers, A. E., Finlayson, E. V. A., Stukel, T. A., Lucas, F. L., Batista, I., Welch, H. G., and Wennberg, D. E. 2002. New England Journal of Medicine 346: 1128-37.

[56] Davoli, M., Amato, L., Minozzi, S., Bargali, A. M., Vecchi, S., and Peruzzi, C. A. 2005. "Volume and Health Outcomes: an Overview of Systematic Reviews." Epidemiologia e Prevenzione 29 (3-4): 3-63.

[57] Thiemann, D. R., Coresh, J., Oetgen, W. J., and Powe, N. R. 1999. "The Association between Hospital Volume and Survival after Acute Myocardial Infarction in Elderly Patients." New England Journal of Medicine 340: 1640-8.

[58] Bankauskaite, V., Dubois, H. F. W., and Saltman, R. B. 2007. Patterns of decentralization across European health systems. In: Saltman RB, Bankaukaite V, Vrangbæk K, editors. Decentralization in health care. Maidenhead: McGraw-Hill Open University Press.

[59] Ellencweig, A. Y. 1992. Analysing health systems. A modular approach. Oxford: Oxford University Press.

[60] Aas, I. H. M. 1991. Malpractice. Quality Assurance in Health Care 3: 21-39.

[61] March, J. G., and Olsen, J. P. 1995. Democratic governance. New York: The Free Press.

[62] Pollitt, C., Birchall, J., and Putman, K. 1998. Decentralising public service management. London: McMillan Press Ltd.

[63] From, J., and Sitter, N. 2002. Hva er governance? [What is governance?]. Plan; No. 6: 22-25.

[64] Nishtar, S. 2004. "Public-private 'partnerships' in Health - a Global Call to Action." Health Research Policy and Systems 2: 5 (doi: 10.1186/1478-4505-2-5).

[65] Tomov, T., Voren van, R., Keukens, R., and Puras, D. 2007. Mental health policy in former eastern bloc countries. In: Saltman RB, Bankaukaite V, Vrangbæk K, editors. Decentralization in health care. Maidenhead: McGraw-Hill Open University Press.

[66] Ham, C. 1996. "Managed Markets in Health Care: the UK Experiment." Health Policy 35: 279-92.

[67] Grimshaw, D., Willmott, H., and Rubery, J. 2005. Inter-organizational networks: Trust, power, and the employment relationship. In: Marchington M, Grimshaw D, Rubery J, editors. Fragmenting work: blurring organizational boundaries and disordering hierarchies. Oxford: Oxford University Press.

[68] Moynihan, R., Oxman, A. D., Lavis, J. N., and Paulsen, E. 
2008. Evidence-informed health policy: Using research to make health systems healthier. Oslo: Norwegian Knowledge Centre for the Health Services; (Rapport $\mathrm{Nr}$ 1-2008).

[69] Murray, C. J. L., and Frenk, J. 2000. "A Framework for Assessing the Performance of Health Systems." Bulletin of the World Health Organization 78: 717-31.

[70] Knapp, M., McDaid, D., Mossialos, E., and Thornicroft, G. 2007. Mental health policy and practise across Europe: an overview. In: Knapp M, McDaid D, Mossialos E, Thornicroft G, editors. Mental health policy and practice across Europe. Maidenhead: McGraw-Hill Open University Press.

[71] Ford, E. W., Wells, R., and Bailey, B. 2004. "Sustainable Network Advantages: a Game Theoretic Approach to Community-based Health Care Coalitions." Health Care Management Review 29: 159-69.

[72] Ortiz, J., Fottler, M., and Hofler, R. 2005. "Performance of Health Centers in Networks." Health Care Management Review 30: 126-38.

[73] Rosko, M. D., and Proenca, J. 2005. "Impact of Network and Aystem Use on Hospital x-inefficiency." Health Care Management Review 30: 69-79.

[74] Weil, T. P. 2000. "How to Enhance the Efficacy of Health Network Growth." International Journal of Health Planning and Management 15: 17-38.

[75] Hagedoorn, J., and Duysters, J. 2002. "Learning in Dynamic Inter-firm Networks: The Efficacy of Multiple Contacts." Organization Studies 23: 525-48.

[76] Schilling, M. A. 2005. Strategic management of technological innovation. New York: McGraw-Hill Irwin.

[77] Scott, C., and Hofmeyer, A. 2007. "Networks and Social Capital: a Relational Approach to Primary Healthcare Reform." Health Research Policy and Systems 5: 9 (doi: 10.1186/1478-4505-5-9).

[78] Aas, I. H. M. 1997. "Organizational Change: Decentralization in Hospitals." International Journal of Health Planning and Management 12: 103-14.

[79] Knapp, M., and McDaid, D. 2007. Financing and funding mental health care services. In: Knapp M, McDaid D, Mossialos E, Thornicroft G, editors. Mental health policy and practice across Europe. Maidenhead: McGraw-Hill
Open University Press.

[80] Gulbinat, W., Manderscheid, R., Baingana, F., Jenkins, R., Khandelwal, S. et al 2004. "The International Consortium on Mental Health Policy and Services: Objectives, Design and Project Implementation." International Review of Psychiatry 16: 5-17.

[81] Ouchi, W. G. 1977. "The Relationship between Organizational Structure and Organizational Control." Administrative Science Quarterly 22: 95-113.

[82] Gammelsæter, H. 1991. Organisasjonsendring gjennom generasjoner av ledere. Molde: Möreforskning; (Rapport nr 9114; A thesis).

[83] Fesler, J. W. 1968. Centralization and decentralization. In: Sills DL, editor. International encyclopedia of the social sciences. New York: New York Free Press; p. 370-379.

[84] Leana, C. R. 1986. "Predictors and Consequences of Delegation." Academy of Management Journal 29: 754-74.

[85] Smith, B. C. 1979. "The Measurement of Decentralization." International Review of Administrative Sciences 45: 214-22.

[86] Church, J., and Barker, P. 1998. "Regionalization of Health Services in Canada: a Critical Perspective." International Journal of Health Services 28: 467-86.

[87] Ostergren, K., Boni, S., Danishevski, K., and Kaarbøe, O. 2007. Implementation of health care decentralization. In: Saltman RB, Bankaukaite V, Vrangbæk K, editors. Decentralization in health care. Maidenhead: McGraw-Hill Open University Press.

[88] Minas, H., and Cohen, A. 2007. "Why Focus on Mental Health Systems?" International Journal of Mental Health Systems 1: 1 (doi: 10.1186/1752-4458-1-1).

[89] Frenk, J. 1994. "Dimensions of Health System Reform." Health Policy 27: 19-34.

[90] Aas, I. H. M. 1995. "Incentives and Financing Methods." Health Policy 34: 205-20.

[91] Amaddeo, F., Becker, T., Fioritti, A., Burti, L., and Tansella, M. 2007. Reforms in community care: the balance between hospital and community-based mental health care. In: Saltman RB, Bankaukaite V, Vrangbæk K, editors. Decentralization in health care. Maidenhead: McGraw-Hill Open University Press. 